\title{
Welfare Analysis of Households Involved in Involuntary Resettlement in Koto Panjang
}

\author{
Fery Andrianus $^{a *}$, Syafruddin Karimi ${ }^{b}$, Melinda Noer $^{c}$, Werry Darta Taifur ${ }^{b}$ \\ ${ }^{a}$ Graduate Program, Universitas Andalas, Kampus UNAND Limau Manis, Padang, West Sumatra 25163, Indonesia \\ ${ }^{b}$ Faculty of Economics, Universitas Andalas, Kampus UNAND Limau Manis Padang, West Sumatra 25163 Indonesia \\ ${ }^{c}$ Faculty of Agriculture, Universitas Andalas, Kampus UNAND Limau Manis Padang, West Sumatra 25163 Indonesia
}

ARTICLE INFO

\section{Article history:}

Received 18 July 2017

Received in revised form 3 April

2018

Accepted 10 April 2018

Keywords:

Involuntary Resettlement,

compensation,

participation
A B S T R A C T

It has been said that development requires sacrifice. This has been the experience of households living in Koto Panjang, Sumatra, Indonesia. Because of new dam construction, they have had to move to new settlements provided by the government. The displaced community consists of 4868 families from 10 villages. Many problems have arisen due to this removal. This study examines the influence of household participation and compensation on household welfare by using a Structural Equation Model. The sample consisted of 360 household heads from 12 villages in Koto Panjang whose households had been moved. The results show that compensation positively and significantly affected household welfare, while household participation could not be proven to affect household welfare.

\section{Introduction}

Dam construction causes displacement when people have to forcibly move to new resettlement locations. The government anticipates involuntary resettlement for displaced households by replacing the lost land, providing housing, providing access to resources and restoring community livelihoods (Perera, 2014).

The purpose of involuntary resettlement is to reconstruct people's lives for the better. However, previous research indicates that often involuntary resettlement tends to negatively impact people's lives economically, socially and environmentally. Economically, homes, assets and livelihoods are lost (Yasuyuki, 1998; Akbar, 2004; JBIC; 2004; Wiranata, 2010; Uslaini and Purwanto, 2015). The simultaneous loss of assets and livelihoods cause households to lose their ability to provide for their daily needs, resulting in a decline in welfare.

Involuntary resettlement generally involves households that are not ready to move, are less

\footnotetext{
* Corresponding author

E-mail address: feryandrianus2007@gmail.com
} 
dynamic, lack the initiative to adapt to new environments or are resistant to relocation (ADB, 1995). Because of this, vulnerable households may fail to reconstruct life successfully in new locations. In order for households to reconstruct their lives, sufficient timely compensation in cash or non-cash must be provided (World Bank, 2000).

Compensation is an urgent requirement to improve household welfare. Inadequate compensation causes a decline in people's welfare. Research has shown that the government's promised compensation for the Koto Panjang community did not materialize as previously agreed (Yasuyuki, 1998; Akbar, 2004; Wiranata, 2010). Insufficient compensation for assets and land disheartened the people deeply, as their hopes for better conditions and wellbeing from the compensation did not materialize. As a result of this, the public protested and this culminated in a court directive in March 2015 which rejected the Koto Panjang community demands as did the Japanese court even though the dam was funded with Japanese aid money (Uslaini and Purwanto, 2015).

Low household participation indicated that the resettlement program in Koto Panjang was more dominantly determined by the central government. The integration and involvement of local stakeholders did not go well (Karimi, et al, 2009; Uslaini and Purwanto, 2015). This is recognized by the government as a mistake, but improvements to reform the development paradigm have not yet been implemented. The role of local communities has not been optimized and their involvement in planning and decision making is minimal. The government still regard them as a passive object of involuntary resettlement, not as active players having a greater role in influencing community acceptance.

Compensation and participation are two vital factors affecting the welfare of displaced households. Therefore, both of these factors were examined in the case of households that were moved in Koto Panjang. Previous research has not studied compensation, participation and welfare simultaneously, therefore this study uses a Structural Equation Model to find the relationship between these three key variables.

\section{Material and Methods}

Improved welfare can be a positive effect of resettlement if dam construction leads to a better life for the affected community. Welfare was measured using the 10 indicators (BPS, 2015); health, education, job, household income, family harmony, leisure time availability, social relationships, house and assets, environment, and also security. Two key factors thought to influence these are community participation and compensation. Community participation consists of involving the community in planning, implementation, maintenance and resulting utilization of the new initiatives (Finsterbusch and Wicklyn, 1987).

Compensation can be in the form of cash (money) and non-cash (land, goods and plant). (ADB, 1998; Cernea, 2003; Fujikura and Nakayama, 2013).

This study will test the hypothesis that both compensation and household participation affect household welfare. This hypothesis builds on the argument that:

a. Households will increase their welfare if they receive compensation from loss of assets owned. Thus compensation is an asset or initial resource that settlers have in reorganizing their new lives. If the promised compensation is in accordance with the wishes of the community and paid on time, then it will impact on improving household welfare.

b. Household participation in the involuntary resettlement program is urgent to prevent potential risks and accommodate household interests. Stages of household participation consist of program planning, implementation and monitoring. If household participation goes well and the government initiated program accommodates household interests, it is believed that the involuntary resettlement program will succeed and provide for the welfare of the household.

The simultaneous relationships between compensation, participation and welfare are pictured in the conceptual framework of Figure 1. The path diagram (Figure 2) shows the relationships between the variables used in the 
Structural Equation Model (SEM). There are 5 latent variables and 30 manifest variable involved in the model. The description of variables and indicators is presented in Table 1 .

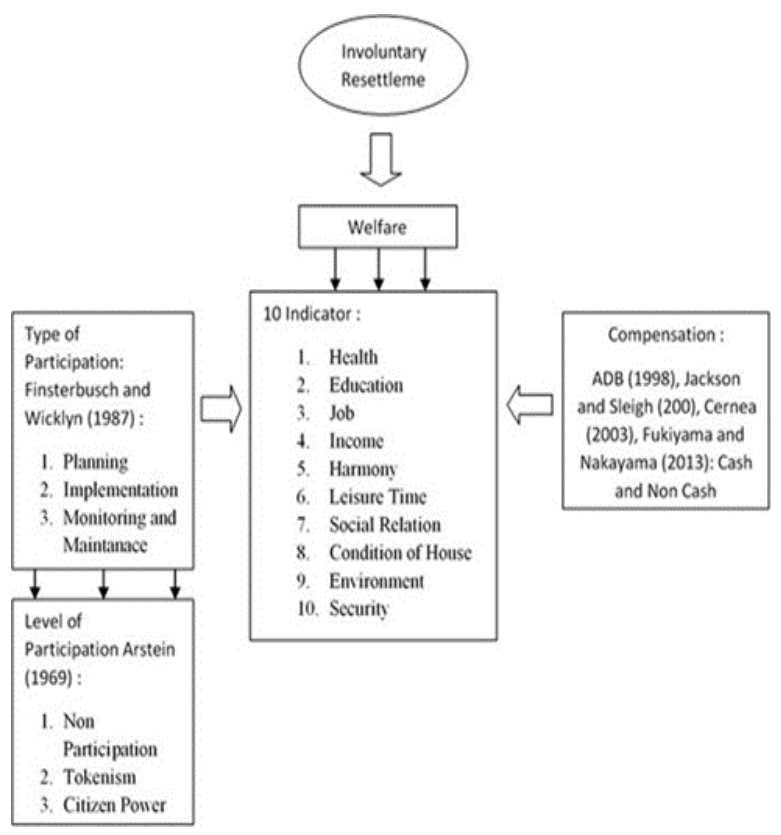

Figure 1 - Conceptual Framework

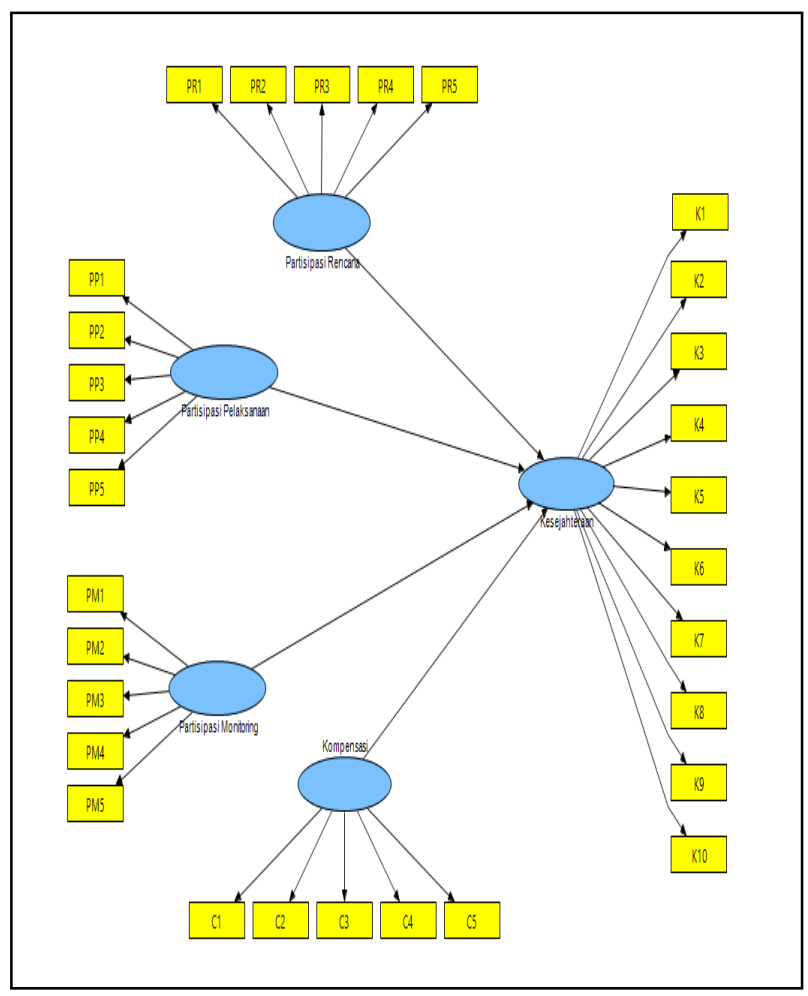

Figure 2 - Path Diagram of DAM Involuntary Resettlement in Koto Panjang
Table 1. Description of Variables and Indicators

\begin{tabular}{|c|c|c|}
\hline Latent Variable & Code & Manifest Indicators \\
\hline \multirow{10}{*}{$\begin{array}{c}\text { Welfare } \\
\text { (Kesejahteraan) }\end{array}$} & K1 & Health, \\
\hline & $\mathrm{K} 2$ & Education, \\
\hline & K3 & Job, \\
\hline & K4 & Household income, \\
\hline & $\mathrm{K} 5$ & Family harmony, \\
\hline & K6 & Leisure time availability, \\
\hline & K7 & Social relation, \\
\hline & K8 & House and asset, \\
\hline & K9 & Environment \\
\hline & K10 & Security. \\
\hline \multirow{5}{*}{$\begin{array}{c}\text { Planning } \\
\text { Participation } \\
\text { (Partisipasi } \\
\text { Rencana) }\end{array}$} & PR1 & No participation \\
\hline & PR2 & Tokenism \\
\hline & PR3 & Tokenism \\
\hline & PR4 & Citizen Power \\
\hline & PR5 & Citizen Power \\
\hline \multirow{5}{*}{$\begin{array}{c}\text { Implementation } \\
\text { Participation } \\
\text { (Partisipasi } \\
\text { Pelaksanaan) }\end{array}$} & PR1 & No participation \\
\hline & PR2 & Tokenism \\
\hline & PR3 & Tokenism \\
\hline & PR4 & Citizen Power \\
\hline & PR5 & Citizen Power \\
\hline \multirow{5}{*}{$\begin{array}{c}\text { Monitoring } \\
\text { Participation } \\
\text { (Partisipasi } \\
\text { Monitoring) }\end{array}$} & PR1 & No participation \\
\hline & PR2 & Tokenism \\
\hline & PR3 & Tokenism \\
\hline & PR4 & Citizen Power \\
\hline & PR5 & Citizen Power \\
\hline \multirow{5}{*}{$\begin{array}{l}\text { Compensation } \\
\text { (Kompensasi) }\end{array}$} & $\mathrm{C} 1$ & Money \\
\hline & $\mathrm{C} 2$ & Building Area \\
\hline & $\mathrm{C} 3$ & Surface Area \\
\hline & $\mathrm{C} 4$ & Farmer Land Area \\
\hline & $\mathrm{C} 5$ & Garden Area \\
\hline
\end{tabular}

Table 2 - Research Location and Total Respondents

\begin{tabular}{|c|c|c|c|}
\hline No & Village & HH & $\begin{array}{l}\text { District/City/ } \\
\text { Province }\end{array}$ \\
\hline 1 & Pulau Gadang & 30 & \multirow{8}{*}{$\begin{array}{l}\text { Kecamatan XIII } \\
\text { Koto Kampar } \\
\text { Kabupaten Kampar } \\
\text { Provinsi Riau }\end{array}$} \\
\hline 2 & Koto Masjid & 30 & \\
\hline 3 & Tanjung Alai & 30 & \\
\hline 4 & Batu Bersurat & 30 & \\
\hline 5 & $\begin{array}{l}\text { Pongkai } \\
\text { Istiqomah }\end{array}$ & 30 & \\
\hline 6 & Koto Tuo & 30 & \\
\hline 7 & Muara Takus & 30 & \\
\hline 8 & Gunung Bungsu & 30 & \\
\hline 9 & Mayang Pongkai & 30 & $\begin{array}{l}\text { Kecamatan Kampar } \\
\text { Kiri Tengah } \\
\text { Kabupaten Kampar } \\
\text { Provinsi Riau }\end{array}$ \\
\hline 10 & $\begin{array}{l}\text { Muara Mahat } \\
\text { Baru }\end{array}$ & 30 & $\begin{array}{c}\text { Kecamatan Tapung } \\
\text { Kabupaten Kampar } \\
\text { Provinsi Riau } \\
\end{array}$ \\
\hline 11 & $\begin{array}{l}\text { Nagari Tanjung } \\
\text { Balik }\end{array}$ & 30 & \multirow{2}{*}{$\begin{array}{c}\text { Kecamatan } \\
\text { Pangkalan Koto Baru } \\
\text { Kabupaten } 50 \text { Kota } \\
\text { Provinsi Sumatera } \\
\text { Barat }\end{array}$} \\
\hline 12 & $\begin{array}{l}\text { Nagari Tanjung } \\
\text { Pauh }\end{array}$ & 30 & \\
\hline & Total & 360 & \\
\hline
\end{tabular}




\section{Results and Discussions}

\subsection{Validity Test}

To get a fit Structural Equation Model we need to test for validity and reliability. Convergent and discriminant validity tests were used. The result of convergent testing can be seen in the size of the loading factors for each manifest variable (Table 3 ). As loading factors for each manifest variable were more than 0.5 they can be considered valid and can be included in the model. The result of discriminant validity test can be seen in Table 4 .

Table 3 - Loading Factor for Variable Indicators

\begin{tabular}{|c|c|c|c|c|}
\hline \multirow{2}{*}{ Latent variable } & $\begin{array}{c}\text { Manifest } \\
\text { Variable }\end{array}$ & $\begin{array}{c}\text { Loading } \\
\text { Factor }\end{array}$ & $\begin{array}{c}\text { Critical } \\
\text { Value }\end{array}$ & Conclusion \\
\hline \multirow{2}{*}{$\begin{array}{c}\text { Planning } \\
\text { Participation }\end{array}$} & PR4 & 0.9590 & 0.5 & Valid \\
\cline { 2 - 5 } & PR4 & 0.9590 & 0.5 & Valid \\
\cline { 2 - 5 } $\begin{array}{c}\text { Implementatio } \\
\text { n Participation }\end{array}$ & PR2 & 0.6413 & 0.5 & Valid \\
\cline { 2 - 5 } Compensation & CP3 & 0.7258 & 0.5 & Valid \\
\hline \multirow{2}{*}{ Welfare } & C5 & 0.8215 & 0.5 & Valid \\
\hline & K5 & 0.7462 & 0.5 & Valid \\
\hline & K9 & 0.6976 & 0.5 & Valid \\
\cline { 2 - 5 } & K10 & 0.6699 & 0.5 & Valid \\
\hline
\end{tabular}

Table 4 - AVE and Communality Test

\begin{tabular}{|c|c|c|c|c|}
\hline Variable & AVE & Communality & $\begin{array}{c}\text { Critical } \\
\text { Value }\end{array}$ & Conclusion \\
\hline $\begin{array}{c}\text { Planning } \\
\text { Participation }\end{array}$ & 0.5881 & 0.5444 & 0.5 & Valid \\
\hline $\begin{array}{c}\text { Implementation } \\
\text { Participation }\end{array}$ & 0.6099 & 0.6776 & 0.5 & Valid \\
\hline Compensation & 0.6776 & 0.6099 & 0.5 & Valid \\
\hline Welfare & 0.5444 & 0.5881 & 0.5 & Valid \\
\hline
\end{tabular}

All variables have an average variance extracted (AVE) value and communality value greater than 0.5 indicating all construct variables are valid according to the communality test.

\subsection{Reability Test}

Both Composite and Cronbach's Alpha reliability tests were conducted. A group of indicators measuring one variable has good composite reliability if the value of the composite readability is greater than 0.7 and the value of Cronbach's Alpha more than 0.6. According to these criteria, both the composite reliability and Cronbach's Alpha test showed that each of the construct variables could be considered reliable (Table 5 ).

Tabel 5 - Reability Test

\begin{tabular}{|l|c|c|c|}
\hline \multicolumn{1}{|c|}{ Variable } & $\begin{array}{c}\text { Composite } \\
\text { Reliability }\end{array}$ & $\begin{array}{c}\text { Cronbachs } \\
\text { Alpha }\end{array}$ & Conclusion \\
\hline $\begin{array}{l}\text { Planning } \\
\text { Participation }\end{array}$ & 0.8081 & 0.6773 & Reliable \\
\hline $\begin{array}{l}\text { Implementation } \\
\text { Participation }\end{array}$ & 0.8222 & 0.7136 & Reliable \\
\hline Compensation & 0.8007 & 0.6259 & Reliable \\
\hline Welfare & 0.8257 & 0.7291 & Reliable \\
\hline
\end{tabular}

\section{SEM Analysis and Hypothesis Test}

These tests of validity and reliability indicate that these 12 indicators can be used to model the 4 constructs with each construct value having 2 to 5 constituent indicators. Figure 3 shows the direct and indirect influence between constructs in the analysis.

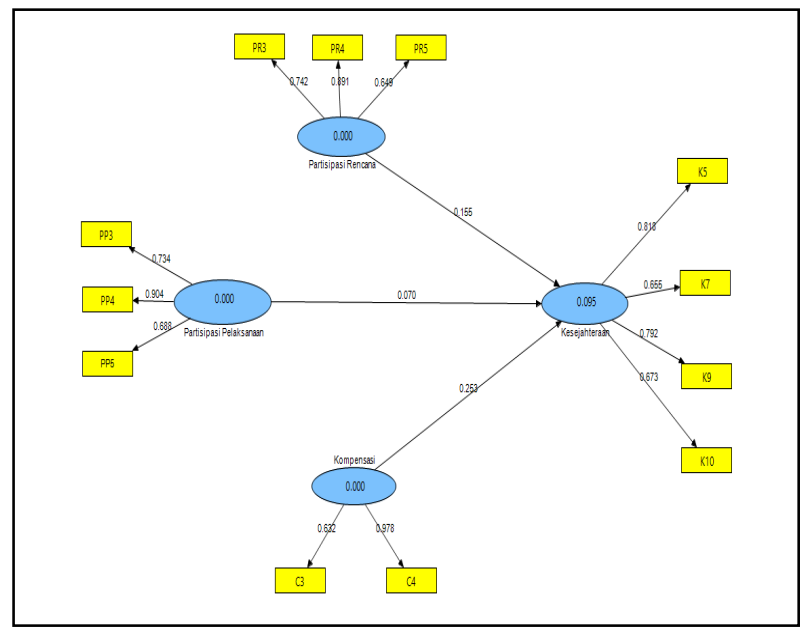

Figure 3 - Path Diagram

Compensation and active householder participation in planning appear to be positively correlated with welfare in Koto Panjang. However, more rigorous analysis shows that the only statistically significant influence on household welfare is compensation which has a t-statistic >1.6 $($ alpha $=10 \%)$. 
Tabel 6 - Hypothesis Test and Path Coefficients (Mean, STDEV, T-Value)

\begin{tabular}{|l|c|c|c|c|c|}
\hline Causality & $\begin{array}{c}\text { Original } \\
\text { Sample } \\
(\mathbf{O})\end{array}$ & $\begin{array}{c}\text { Sample } \\
\text { Mean } \\
(\mathbf{M})\end{array}$ & $\begin{array}{c}\text { Standard } \\
\text { Deviation } \\
\text { (STDEV) }\end{array}$ & $\begin{array}{c}\text { Standard } \\
\text { Error } \\
(\text { STERR) }\end{array}$ & $\begin{array}{c}\text { T Statistics } \\
(\text { (O/STERR) }\end{array}$ \\
\hline $\begin{array}{l}\text { Compensati } \\
\text { on -> } \\
\text { Welfare }\end{array}$ & 0.253479 & 0.248658 & 0.151995 & 0.151995 & 1.667678 \\
\hline $\begin{array}{l}\text { Implementati } \\
\text { on -> Welfare }\end{array}$ & 0.069747 & 0.039528 & 0.168265 & 0.168265 & 0.414510 \\
\hline $\begin{array}{l}\text { Planning -> } \\
\text { Welfare }\end{array}$ & 0.155072 & 0.136467 & 0.173134 & 0.173134 & 0.895680 \\
\hline
\end{tabular}

The interpretation of this result is if adequate or more compensation was received by the community it would effectively improve their welfare. This observation is based on the results from the field showing that the communities receiving adequate compensation had better welfare outcomes than those who failed to receive adequate compensation. Furthermore, the hypothesis that community participation influences household welfare was not proved in this research. The citizens who were moved had no choice but to accept what the Government provided. No provision for active participation that may have benefited them in the relocation process was available. This has also often been found to be the case in previous research into citizen participation in relocation programs in Africa and Thailand and other parts of Indonesia where the community is treated as a passive object rather than an active stakeholder.

\section{Conclusion}

This study has discussed the welfare, participation and compensation to communities in Koto Panjang that were involuntarily resettled because of the effect of dam construction in Koto Panjang. The empirical results showed that compensation had a significant positive effect on the welfare of households while people participation had no measurable effect on the welfare of households. It showed that provision for active household participation was lacking. To increase the welfare of displaced communities like those in Koto Panjang, the government should ensure that compensation is adequate and the households are actively involved in the resettlement process so that resettlement is conducted in a way that impacts the affected households and surrounding districts more positively.

\section{References}

ADB. (1995). Involuntary Resettlement. Accessed from :

http://www.adb.org/sites/default/files/institut ionaldocument/32515/files/involuntyresettlement.pdf

Akbar, Ali. (2004). Dampak Pembangunan PLTA Koto Panjang Terhadap Pengembangan Wilayah di Kecamatan XIII Koto Kampar. Tesis Perencanaan Pembangunan Wilayah dan Perdesaan. Program Pascasarjana Universitas Sumatera Utara.

Arnstein, S. R. (1969). A Ladder of Citizen Participation. JAIP. Vol. 35, No. 4, 216-224.

BPS. (2015). Indikator Kesejahteraan Rakyat Tahun 2015.

Cernea, M. M. (2003). For a New Economics of Resettlement: A Sociological Critique of the Compensation Principle International Social Science Journal, 2003, nr 175 ( UNESCO, Paris: Blackwell)

Fujikura, R., Nakayama, M (2013): The long-term impacts of resettlement programmes resulting from dam construction projects in Indonesia, Japan, Laos, Sri Lanka and Turkey: a comparison of land-for-land and cash compensation schemes. International Journal of Water Resources Development. 29:1, 4-13.

Finsterbusch, K., Wicklin III, W. A. V. (1987). The contribution of beneficiary participation to development project effectiveness. Public Administration and Development, Vol 7, 123.

Jackson, S., Sleigh, A. C. (2001). The Political Economy and Socio-Economic Impact of China's Three Georges Dam. Asian Studies Review 25, 57-72.

JBIC (2004). Kota Panjang Hydroelectric Power and Associated Transmission Line Project (1) (2): Third Party Ex-Post Evaluation Report. Japan Bank for International Corporation (JBIC). 
Karimi, S., Nakayama, M., \& Takesada, N. (2009). Poverty in Koto Panjang resettlement villages of West Sumatra: An analysis using survey data of families receiving cash compensation. International Journal of Water Resources Development, 25, 459-466.

Perera, J. (Ed.). (2014). Lose to gain: Is involuntary resettlement a development opportunity? Mandaluyong City, Philippines: Asian Development Bank.

Saleh., R, M. (2007) Bendungan Besar : Petaka Dibalik Mitologi Kesejahteraan. Walhi Jabar, Desember 2007. https://walhijabar.wordpress.com/2007/12/25 /bendungan-besar-petaka-dibalik-mitologikesejahteraan/

Uslaini, Purwanto, W. (2015). Skema Pembiayaan Infrastruktur yang Bersandar pada Investasi
Asing; Mengulang Kesalahan Krisis Tahun 80-an: Studi Kasus Dam Koto Panjang. "Dilema Nawa Cita dan Lingkungan yang Berkelanjutan Pemerintahan Jokowi - JK". Jurnal Tanah Air.Walhi. Edisi Agustus

Wiranata, A. M, I (2010). Mengkritik Makna Hegemonik Pembangunan Berkelanjutan Studi Kasus: Proyek NAM di Lembah Sungai Rarmada, Jurnal Ilmiah Fakultas Ilmu Sosial dan Ilmu Politik Vol. I No. 01, Tahun 2010. Universitas Udayana Bali.

World Bank (2000). Involuntary Resettlement: The Large Dam Experience. Precis 194.. 